\title{
Therapeutic Perspectives of Angiotensin-(1-7) in the Treatment of Cardiovascular Disease
}

\author{
Christian Höcht ${ }^{*}, 1,2$, Marcos Mayer ${ }^{1,2}$ and Carlos A. Taira ${ }^{1,2}$ \\ ${ }^{1}$ Cátedra de Farmacología, ${ }^{2}$ Instituto de Fisiopatología y Bioquímica Clínica, Facultad de Farmacia y Bioquímica, \\ Universidad de Buenos Aires, Junín 956, (C1113AAD) Buenos Aires, Argentina
}

\begin{abstract}
In the last decade, new biologically active components of the renin-angiotensin system were found. Angiotensin-(1-7) (Ang-(1-7)), a metabolite of angiotensin I and angiotensin II (Ang II), is considered the most pleiotropic component of the renin-angiotensin system, acting as a counterregulatory mediator of Ang II. Ang-(1-7) exerts beneficial effects on the cardiovascular system, including reduction of blood pressure, myocardial antihypertrofic and antifibrotic actions, and reversal of renal dysfunction, among others. Recent discovery of enzymatic pathways involved in Ang-(1-7) synthesis, such as the angiotensin-converting enzyme-2 (ACE2) and the existence of a specific receptor to this heptapeptide, the Mas receptor, have increased interest in the design of therapeutic strategies aimed at increasing the biological actions of Ang-(1-7). ACE inhibitors, $\mathrm{AT}_{1}$ receptor blockers and aldosterone antagonists enhance Ang-(1-7) levels by different mechanisms. Actually, non-peptidic Ang-(1-7) agonists and ACE2 activators are under development and could have a role in the treatment of cardiovascular diseases.

The aim of the present review is to describe the biochemical and physiological actions of Ang-(1-7), the therapeutic strategies designed to enhance Ang-(1-7) activity foccusing in their possible role and limitations in the treatment of cardiovascular disease.
\end{abstract}

Keywords: Angiotensin-(1-7), angiotensin-converting enzyme-2, cardiovascular disease, Mas receptor.

\section{INTRODUCTION}

The renin-angiotensin system (RAS) is a peptidergic system with endocrine characteristics. Angiotensinogen is released from the liver and cleaved by renin to the decapeptide angiotensin (Ang) I. Ang I is then activated to the octapeptide Ang II by angiotensin converting enzyme (ACE) [1]. This view of RAS has been expanded by further findings that demonstrate the existence of different Ang receptors ( $\mathrm{AT}_{1}$, $\mathrm{AT}_{2}, \mathrm{AT}_{4}$ ), signal transduction pathways and alternative metabolic cascades; and the discovery of additional truncated peptides with biological activity, such as Ang-(2-8) (Ang III), Ang-(3-8) (Ang IV), and Ang-(1-7) [1]. Ang-(1-7) have gained high attraction considering its counterregulatory effects with regards to Ang II actions, and the fact that Ang-(17) is formed from Ang II by the action of ACE2 [1]. More recently, the discovery of a specific binding site to Ang-(17), named Mas receptor, confirmed the relevance of Ang-(17 ) in the regulation of cardiovascular function $[2,3]$. The G-protein-coupled receptor Mas was reported to act as a physiological antagonist of the Ang II type-1 receptor, considering that this receptor can hetero-oligomerize with $\mathrm{AT}_{1}$ receptor, inhibiting Ang II actions [4].

Taking into account the importance of Ang-(1-7) in normal physiology and pathophysiology, the aim of the present review is to comment the main mechanisms of action,

*Address correspondence to this author at the Cátedra de Farmacología, Facultad de Farmacia y Bioquímica, Universidad de Buenos Aires, Junín 956, (C1113AAD) Buenos Aires, Argentina; Tel: +(54-11)-4964-8265; Fax: +(54-11)-4508-3645; E-mail: chocht@ffyb.uba.ar physiological functions and the pharmacological perspectives of Ang-(1-7) modulation. Several works have previously reviewed the biochemical and physiological aspects of Ang-(1-7). Therefore, the present review will be focussed on pharmacological aspects of drugs acting at the ACE2-Ang(1-7)-Mas receptor axis, emphasizing on the possible therapeutic role and limitations of strategies aimed at increasing endogenous Ang-(1-7) levels or Mas receptor activation.

\section{ANGIOTENSIN-(1-7) METABOLIC PATHWAYS: ROLE OF ACE-2}

Synthesis of Ang-(1-7) is regulated by three known enzymes, including neprilysin 24.11 (NEP), thimet oligopeptidase 24.15 (TOP), and prolyl oligopeptidase 21.26 (POP) [5] (Fig. 1). Additionally, angiotensin-converting enzyme-2 (ACE2), which shares $42 \%$ sequence identity to the catalytic domain of ACE [5] but is insensitive to ACE inhibitors, mediates the conversion of Ang I into Ang-(1-9), as well as the conversion of Ang II into Ang-(1-7). Therefore, ACE2 regulates in a double fashion the production of Ang-(1-7): indirectly through the cleavage of Ang I into Ang-(1-9) (which can be further metabolized into Ang-(1-7) by ACE), and directly by means of the conversion of Ang II into Ang-(1-7) (Fig. 1). Nevertheless, direct synthesis of Ang-(1-7) seems to be most kinetically favored, considering that ACE 2 shows a higher substrate preference for Ang II than for Ang I [6].

Ang-(1-7) has a short half-life (about 10 seconds in plasma) in rodent because of its peptidic nature [7]. However, half-life of Ang-(1-7) is approximately $29-30 \mathrm{~min}$ in humans [8]. ACE contributes to its metabolism, leading to the formation of the inactive metabolite Ang-(1-5) [9]. A1ternative pathways are also involved in Ang-(1-7) degrada- 


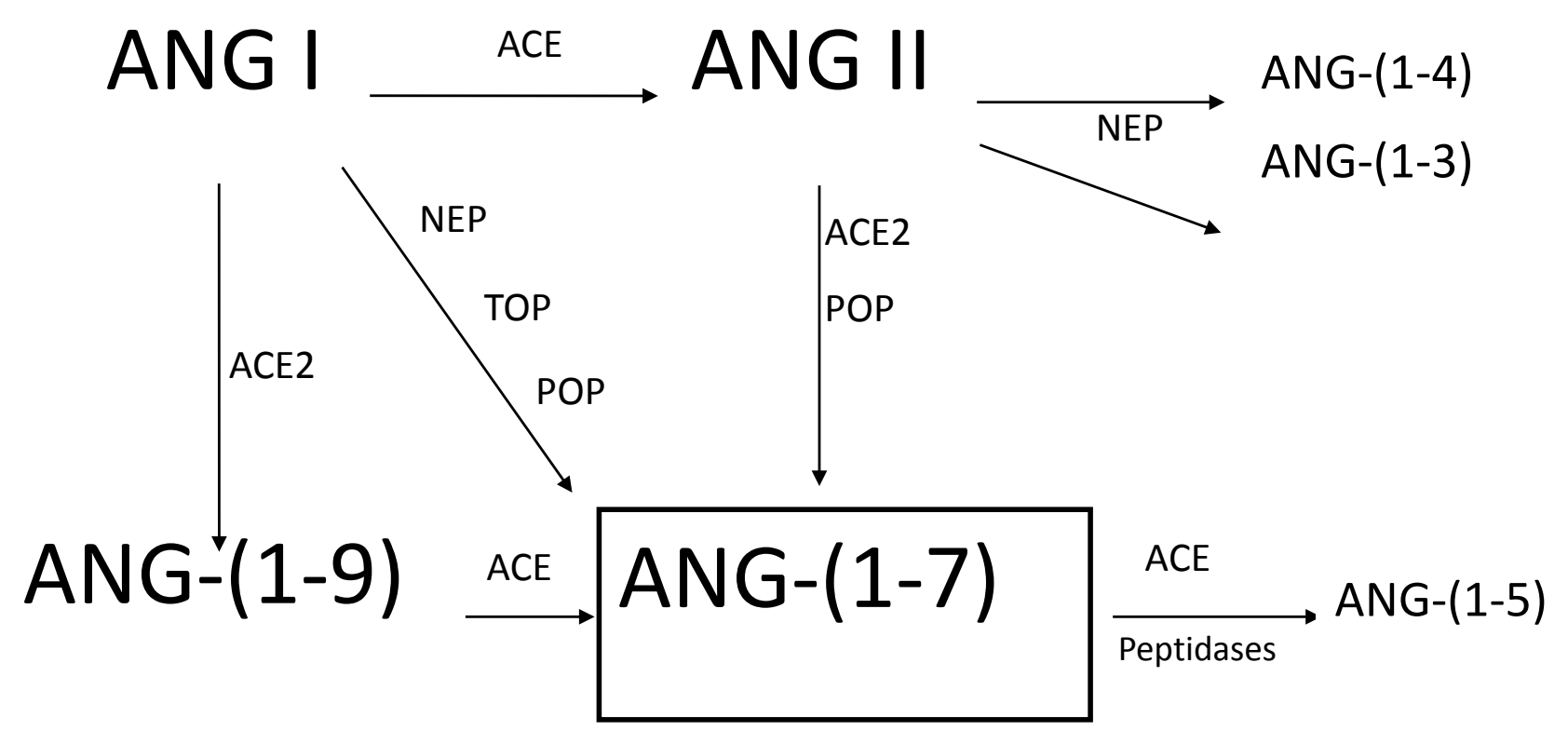

Fig. (1). Angiotensin-(1-7) synthesis and metabolism. ANG I: Angiotensin I; ANG II: Angiotensin II; ANG-(1-4): Angiotensin-(1-4); ANG(1-3): Angiotensin-(1-3); ANG-(1-9): Angiotensin-(1-9); ANG-(1-7): Angiotensin-(1-7); ACE: Angiotensin Converting Enzyme; ACE2: Angiotensin Converting Enzyme 2; NEP: neprilysin 24.11; TOP: Thimet oligopeptidase 24.15; POP: Prolyl oligopeptidase 21.26. Adapted form ref. [3].

tion in different tissues, considering that NEP can hydrolyze the 4-tyrosine, 5-isoleucine (Tyr4-Ile5) bond of Ang-(1-7) to form Ang-(1-4) in the kidney [9].

\section{PHARMACODYNAMIC FEATURES}

The orphan $G$ protein-coupled receptor Mas has been identified as the molecular target involved in physiological actions of Ang-(1-7) [2, 3, 10], considering that most effects of the heptapeptide can be blocked by its specific antagonist D-Ala ${ }^{7}$-Ang-(1-7) [11]. More recently, Silva et al. reported pharmacological evidence for the existence of a different Ang-(1-7) receptor subtype mediating the vasodilator effect of the heptapeptide in the aorta from Sprague Dawley rats [12]. The vasodilator effect induced by the peptide is mediated by activation of Ang-(1-7) receptors sensitive to D-Pro ${ }^{7}$ Ang-(1-7) but not to D-Ala ${ }^{7}$-Ang-(1-7) and is dependent on endothelium derived nitric oxide (NO) [12].

Main signaling pathways involved in Ang-(1-7) responses by means of Mas receptor stimulation include PI3Kdependent Akt phosphorylation, leading to NO production by phosphorylation of NO synthase [13]; inhibition of mitogen-activated protein kinase (MAPK) phosphorylation [14]; stimulation of phospholipase $\mathrm{A}_{2}$ activity and consequently release of arachidonic acid for prostanoid production [15]; and, finally, prostacyclin-mediated production of cAMP and activation of cAMP-dependent protein kinase.

Ang-(1-7) inhibits Ang II-mediated MAPK phosphorylation, and partly suppresses Ang II-stimulated increase in the profibrotic cytokine transforming growth factor- $\beta_{1}\left(\right.$ TGF- $\left.\beta_{1}\right)$ [16]. In addition, Giani et al. [17] have recently postulated that Ang-(1-7) could be a positive physiological contributor to the actions of insulin in heart, considering that Ang-(1-7) stimulated cardiac Akt phosphorylation, meanwhile acute invivo insulin-induced cardiac Akt phosphorylation was inhibited by Ang II.

Another interaction was described between Ang-(1-7) and bradykinin, which would participate in the potentiation of bradykinin response after ACE inhibitor therapy. Although the exact mechanisms involved are not completely understood, it has been proposed that ACE inhibition, nonhydrolytic interaction with ACE favoring a crosstalk between $\mathrm{ACE}$ and bradykinin $\mathrm{B}_{2}$ receptor and receptor Masmediated changes in the coupling and/or signaling of bradykinin [18] could be some of the mechanisms involved.

Although most of Ang-(1-7) effects seem to be mediated by Mas receptor activation, this heptapeptide is also able to interact with $\mathrm{AT}_{1}$ and $\mathrm{AT}_{2}$ receptors [19-24]. In the case of $\mathrm{AT}_{1}$ and $\mathrm{AT}_{2}$ receptors, the low affinity of Ang-(1-7) for them makes it difficult to conceive that Ang-(1-7) acts as a physiological agonist in normal conditions. However, experimental data confirm the ability of Ang-(1-7) to interact with $\mathrm{AT}_{1}$ and $\mathrm{AT}_{2}$ receptors when it is administered in high pharmacological doses [25].

\section{PATHOPHYSIOLOGICAL ACTIONS OF ANGIO- TENSIN-(1-7)}

Ang-(1-7) regulates cardiovascular function in healthy subjects and cardiovascular disease due to its effects on different tissues (Fig. 2). In many tissues Ang-(1-7) and G-protein-coupled receptor Mas exert counterregulatory actions with regard to Ang II, limiting the deleterious effects of the octapeptide (for review see [3]). The fact that Ang-(1-7) 


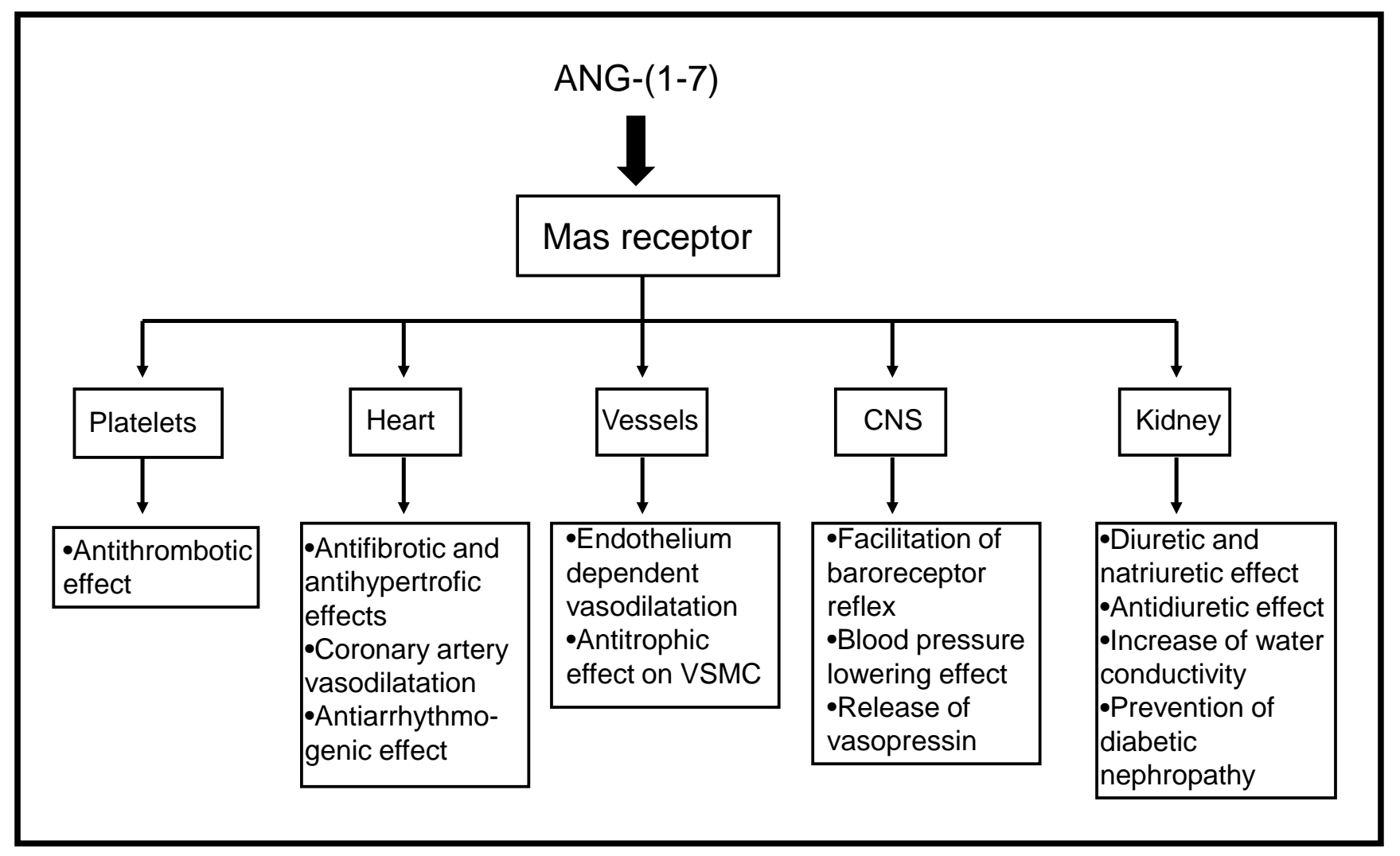

Fig. (2). Cardiovascular actions of angiotensin-(1-7). Abbreviations: CNS: central nervous system; VSMC: vascular smooth muscle cells.

cardiovascular effects are enhanced in experimental animals with cardiovascular diseases suggests a critical role for the heptapeptide in the development and maintenance of experimental hypertension and heart failure [3].

Although Ang-(1-7) cardiovascular effects have been extensively studied, the exact mechanism of action involved remains partially elusive. Ang-(1-7) exerts its cardiovascular effects mainly by means of Mas receptor activation; nevertheless, blockade of $\mathrm{AT}_{1}$ and $\mathrm{AT}_{2}$ receptors also prevents some actions of the heptapeptide, suggesting a crosstalk between the Mas and Ang II receptors [26]. In addition, enhancement of $\mathrm{NO}$, bradykinin and prostacyclin $\left(\mathrm{PGI}_{2}\right)$ production is also involved in the mechanism of action of Ang(1-7) effects (for review see [27]).

Ang-(1-7) exerts an antithrombotic effect due to stimulation of $\mathrm{NO}$ and $\mathrm{PGI}_{2}$ release. The presence of Mas protein and specific binding for Ang-(1-7) were reported in rat and mouse platelets and the antithrombotic effect could be mediated by NO release from platelets [28]. This effect is enhanced in experimental models of cardiovascular disease, considering that the heptapeptide significantly reduced thrombus weight in $2 \mathrm{~K}-1 \mathrm{C}$ hypertensive rats but not in normotensive animals [29]. Moreover, the antithrombotic effect of Ang-(1-7) was also blocked by an $\mathrm{AT}_{1}$ antagonist.

At the vascular system, Ang-(1-7) shows a vasodilatador action, although the mechanism of action is highly dependent on the vascular bed and animal specie (for review see [1]). Vascular effects of Ang-(1-7) were also evaluated in normotensive and hypertensive patients showing conflicting results. Sasaki et al. [30] found that Ang-(1-7) induced re- laxation in forearm circulation of both normotensive and hypertensive subjects through a mechanism independent of NO. Other authors show a biphasic effect of Ang-(1-7) in rat aorta [31]. Whilst low concentrations of the heptapeptide induced an endothelium dependent vasorelaxation, high doses $\left(10^{-6}-10^{-5} \mathrm{M}\right)$ exerted vasoconstriction through an $\mathrm{AT}_{1}$ receptor dependent mechanism [31].

Regarding the mechanism of Ang-(1-7) vasoactive effect, several reports show that the vascular effect of Ang-(1-7) is endothelium dependent [18] due to increase in NO synthesis, prostaglandins or endothelium-derived relaxing factor (for review see [1]). In addition, vascular effects of the heptapetide could also be a consequence of a complex interaction between Mas receptor and bradykinin $\mathrm{B}_{2}$ and angiotensin $\mathrm{AT}_{2}$. Peiró et al. [32] reported that BK-mediated NO release was increased by Ang-(1-7) and blunted by D-Ala ${ }^{7}$ Ang-(1-7) pretreatment in primary human endothelial cell cultures.

Ang-(1-7) also regulates cardiovascular function by acting at the kidneys, producing complex renal effects [1]. The peptide can regulate fluid homeostasis through different mechanisms, including stimulation of vasopressin release and acting at different nephron segments with variable effects on sodium and water excretion. Several studies have demonstrated a diuretic and natriuretic effect of Ang-(1-7) in different experimental conditions [1]. Conversely, through an action at the distal nephron, Ang-(1-7) induces opposite effects generating a Mas receptor dependent antidiuretic effect in water-loaded rats [33]. In addition, the heptapeptide potently increases water conductivity in the inner medullary collecting duct [34] through a mechanism that involves an 
interaction between Mas receptor and vasopressin $V_{2}$ receptor [35].

Although Ang-(1-7) exerts opposite effects on water and sodium excretion at different segments of the nephron, the antidiuretic effect of the heptapeptide seems to predominate, considering that application of Mas antagonists stimulates renal excretion of sodium and water [1].

It is a well known fact that blood pressure is regulated by the central nervous system mainly through the control of sympathetic outflow. Ang-(1-7) is generated in central nuclei related to blood pressure regulation, such as medullary areas and the hypothalamus $[36,37]$. In normotensive rats, intracerebroventricular administration of the peptide does not modify blood pressure or heart rate, although it facilitates baroreceptor reflex control of heart rate [38]. Conversely, Ang-(1-7) induces a depressor response in situations involving overactivity of Ang II. Cerebroventricular infusion of Ang-(1-7) caused a significant decrease in blood pressure and injections of a specific Ang-(1-7) monoclonal antibody increased blood pressure and heart rate in [mRen-2]27 transgenic hypertensive $(\mathrm{Tg}+)$ rats but not in normotensive rats $[39,40]$. In previous studies from our laboratory $[25,41]$, we found that Ang-(1-7) blocked the pressor response to intrahypothalamic administration of Ang II in spontaneously hypertensive and sinoaortic denervated rats without affecting the hypothalamic effects of Ang II in control normotensive animals.

Central effects of the peptide are also dose-dependent. Whilst the intrahypothalamic administration of a low dose of Ang-(1-7) (5 pmol) in sinoaortic denervated rats induced a reduction of blood pressure, a higher dose $(50 \mathrm{pmol})$ was without effect [25]. Moreover, the higher dose of Ang-(1-7) causes a reduction in mean arterial pressure in the presence of the $\mathrm{AT}_{1}$ antagonist, suggesting that Ang-(1-7) at high doses does not only bind to Mas receptor but also to $\mathrm{AT}_{1}$ receptors [25].

In addition, Ang-(1-7) may also affect central regulation of blood pressure by changing vasopressin release. It was demonstrated that Ang-(1-7) stimulates vasopressin release with the same potency that Ang II does [42].

Several lines of evidence support a cardioprotective role of Ang-(1-7). Ang-(1-7) exerts antiarrhythmogenic, antifibrotic, antihypertrofic effects and vasodilatation in heart vasculature [1]. In addition, Ang-(1-7) endogenous levels are increased in cardiovascular diseases, including heart failure and acute myocardial infarction [1].

Coronary artery vasodilatation induced by Ang-(1-7) is dependent of bradykinin receptors and NO release [43, 44]. In other experiments, it was also demonstrated that the vasodilatory effect of the heptapeptide in perfused mouse hearts involved an interaction of Mas with $\mathrm{AT}_{1}$ and $\mathrm{AT}_{2}$ receptors [45]. However, higher concentrations of the peptide could exert opposite effects possibly by means of $\mathrm{AT}_{1}$ receptors activation [46].

Ang II decreases conduction velocity and enhances the dispersion of action potential duration in the failing heart inducing cardiac arrhythmias [47]. Considering the counterregulatory actions of Ang-(1-7), an antiarrhythmogenic effect of Ang-(1-7) has been postulated. Ferreira et al. [48] have demonstrated that Ang-(1-7) perfusion reduced the incidence and duration of reperfusion arrhythmias after local ischemia induced by coronary ligation. The antiarrhythmic effect of low concentrations of Ang-(1-7) is mediated by Mas receptor activation and release of endogenous prostaglandins. The heptapeptide also induces hyperpolarization of heart cells and enhances conduction velocity in cardiomyophatic hamsters [49]. However, the authors also found that high concentrations of Ang-(1-7) induce proarrhythmic effects by increasing duration of the action potential and consequently generating early-after depolarizations [49]. Therefore, excessive generation of the heptapeptide in the heart could be harmful by means of increasing the incidence of proarrhythmia.

Ang-(1-7) also exerts cardioprotective effects through inhibition of cardiac hypertrophy and remodeling induced by different adverse stimuli. Different authors found that an increase in cardiac Ang-(1-7) levels prevents cardiac hypertrophy and fibrosis in chronically Ang II infused rats [50], spontaneously hypertensive rats [51] and deoxycorticosterone acetate (DOCA)-salt rat model [52]. Moreover, overproduction of Ang-(1-7) in a transgenic model in rats induces resistance to isoproterenol-induced cardiac hypertrophy [53]. In addition, these transgenic rats showed a reduced duration of reperfusion arrhytmias and an improved post ischemic function in isolated Langerdorff heart preparation [53].

It is also important to mention that antiremodeling effects of the heptapeptide are induced by activation of cardiac Mas receptor and are independent of its effects on blood pressure or Ang II receptors in the cardiac tissue [54]. Co-infusion of AngII and Ang-(1-7) in Sprague Dawley rats results in significant attenuation of myocyte hypertrophy and interstitial fibrosis, without significant effects on blood pressure [54].

Ang-(1-7) also prevents cardiac fibrosis, considering that the heptapeptide reduces collagen synthesis and decreases mRNA expression of growth factors in adult rat cardiac fibroblasts [55]. In addition, pretreatment with Ang-(1-7) inhibits Ang II profibrotic actions [55]. Effects of Ang-(1-7) on cardiac fibrosis are mediated by means of Mas receptor activation, considering that application of A-779 but not $\mathrm{AT}_{1}$ or $\mathrm{AT}_{2}$ reduced the affinity of the heptapeptide to adult rat cardiac fibroblasts [55]. On the other hand, the work of Mercure et al. [56] sustains that cardiac Ang-(1-7) selectively modulates some of the downstream signaling effectors of cardiac remodeling and the heptapeptide can reduce hypertension-induced cardiac remodeling through a direct effect on the heart.

Ang-(1-7) induces antitrophic effects on vascular smooth muscle cells of normotensive rats, possibly by means of increased release of prostaglandins [57], enhancing thereby production of cAMP and activation of cAMP-dependent protein kinase and by attenuation of MAPK activation [58]. Moreover, vascular ACE2 overexpression in spontaneously hypertensive stroke-prone rats reduces hypertension probably by locally degrading Ang II and improved endothelial function [59].

On the other hand, it was demonstrated that Ang-(1-7) reduces in a dose dependent manner the incorporation of $\left[{ }^{3} \mathrm{H}\right]$-thymidine, a biomarker of cellular proliferation, in vascular smooth muscle cells obtained from aorta induced by 
different stimuli, including fetal bovine serum, plateletderived growth factor (PDGF) and Ang II [60]. In addition, chronic administration of Ang-(1-7) diminishes neointimal formation after vascular injury without affecting medial area of the injured or the contralateral uninjured artery, and these effects occurred in the absence of changes in blood pressure [61]. Regarding the receptor involved in the antiproliferative actions of Ang-(1-7), reduced thymidine incorporation induced by Ang-(1-7) was not affected by pretreatment with $\mathrm{AT}_{1}$ or $\mathrm{AT}_{2}$ antagonists, but was prevented by application of [D-Ala] -Ang-(1-7), a Mas receptor blocker [57].

\section{THERAPEUTIC PERSPECTIVES OF ANGIOTENSIN- (1-7)}

As mentioned above, Ang-(1-7), at physiological or pharmacological concentrations, regulates cardiovascular function acting on several tissues. Ang-(1-7) also exerts antiproliferative actions that could be of interest in several cardiovascular diseases including heart failure and atherosclerosis. The potential therapeutic benefit of Ang-(1-7) is also supported by the fact that endogenous Ang-(1-7) levels or the effect of the heptapeptide are modified in pathological conditions. Moreover, Rodgers et al. [62] reported a Phase I/II dose escalation study of Ang-(1-7) administered before and after chemotherapy in patients with newly diagnosed breast cancer.

Preclinical studies have demonstrated the involvement of Ang-(1-7) in blood pressure regulation in different models of hypertension [25, 63-65]. Compromise of Ang-(1-7) in clinical hypertension was also suggested by the fact that urinary excretion of Ang-(1-7) is reduced in essential hypertensive patients with regard to normotensive subjects [66]. Moreover, urinary concentrations of Ang-(1-7) correlated inversely with systolic and diastolic blood pressure.

Beneficial effects of Ang-(1-7) in hypertension are not only related to blood pressure lowering effect, but also to reduction in target organ damage. Grobe et al. [52] have found that chronic infusion of Ang-(1-7) prevented collagen deposition in the DOCA-salt model of hypertension without affecting blood pressure and cardiac hypertrophy. The heptapeptide is also able to prevent cardiac remodeling induced by Ang II. Ang-(1-7) improves renal, cardiac, and vascular function in spontaneously hypertensive rats treated with NGnitro-L-arginine methyl ester (L-NAME) and these effects were similar to many of the beneficial effects of RAS blockade with an ACE inhibitor [64].

Ang-(1-7) also seems to play a protective role during acute myocardial infarction, considering that chronic infusion of the heptapeptide reduces arrhythmias [48] and attenuates development of heart failure after myocardial infarction in rats [67].

Indirect evidence that also supports a role for Ang-(1-7) in cardiovascular pathologies is the fact that ACE2-deficient mice develop cardiomyopathy associated with increased oxidative stress and inflammation, as well as MAPK and PI3K activation [68]. Moreover, Burrell et al. [69] have demonstrated the existence of an increase in ACE2 after myocardial infarction, suggesting that the enzyme plays an important role in the negative modulation of the RAS after cardiac injury.
Clinical studies also indirectly show a protective role of Ang-(1-7) in heart failure. Activity of NEP and ACE2 were increased in failing human heart ventricles, suggesting that enhanced Ang-(1-7) cardiac levels could exert a cardioprotective effect in heart failure [70].

Ang-(1-7) may also have a therapeutic role in the treatment of diabetic complications. Benter et al. [71] have demonstrated that Ang-(1-7) prevents cardiovascular dysfunction in streptozotocin-treated rats, an experimental model of diabetes, suggesting that activation of Ang-(1-7) signal transduction could be an important therapeutic strategy to reduce cardiovascular events in diabetic patients. Diabetic nephropathy could also be reduced by activation of Mas receptor. For instance, Ang-(1-7) or its receptor agonist AVE 0991 attenuates proteinuria and improves renal vascular activity in the diabetic rat [71].

More indirect evidences demonstrated that renal ACE2 is reduced in the proximal tubules of the streptozotocininduced model of type- 1 diabetes, and the attenuation of renal injury by ACE inhibition is associated with increased ACE2 expression [72]. Moreover, chronic ACE2 inhibition in the diabetic $\mathrm{db} / \mathrm{db}$ mice exacerbates the extent of albuminuria in a 3-fold manner [73].

Enhancement of ACE2-Ang-(1-7)-Mas axis seems to be also attractive to overcome insulin resistance, considering that Mas knockout (Mas-/-) mice exhibit many common features of metabolic syndrome [10]. Moreover, recently we have demonstrated that chronic Ang-(1-7) infusion ameliorates insulin resistance in fructose fed rats, an experimental model of metabolic syndrome, through a mechanism that could involve modulation of insulin signaling [74].

On the other hand, other effects were also reported for possible therapeutic perspectives. A role of Ang-(1-7) was also demonstrated in the prevention of certain types of cancer [75], treatment of chemotherapy-induced cytopenias [76] and dermal repair [77]. Moreover, a role of ACE2 in severe acute respiratory syndrome coronavirus (SARS-CoV) induced lung injury in mice. ACE2 could be SARS-CoV receptor in vivo and injection of SARS-CoV spike into mice worsens acute lung failure which can be attenuated by blocking the renin-angiotensin pathway $[78,79]$.

\section{THERAPEUTIC STRATEGIES TO ENHANCE EN- DOGENOUS ANG-(1-7) LEVELS OR MAS RECEP- TOR ACTIVATION}

Taking into account the beneficial effects of Ang-(1-7) and the involvement of the peptide in the pathophysiological state of several diseases, enhancement of the ACE2-Ang-(1-7)Mas axis could be a novel therapeutic strategy in the treatment of cardiovascular diseases. It is known that ACE2 activity, in an Ang-(1-7)-dependent fashion, improves homeosthasis through a mechanism that may involve attenuation of NADPHox-induced reactive oxygen species production. Therefore, enhancement of ACE2 activity may be an interesting approach to limit aberrant vascular responses and atherothrombosis [80].

From a pharmacological perspective, Mas receptor activation could be enhanced either by strategies aimed at increasing endogenous levels of Ang-(1-7) or by the systemic administration of Mas receptor agonists (Fig. 3). 


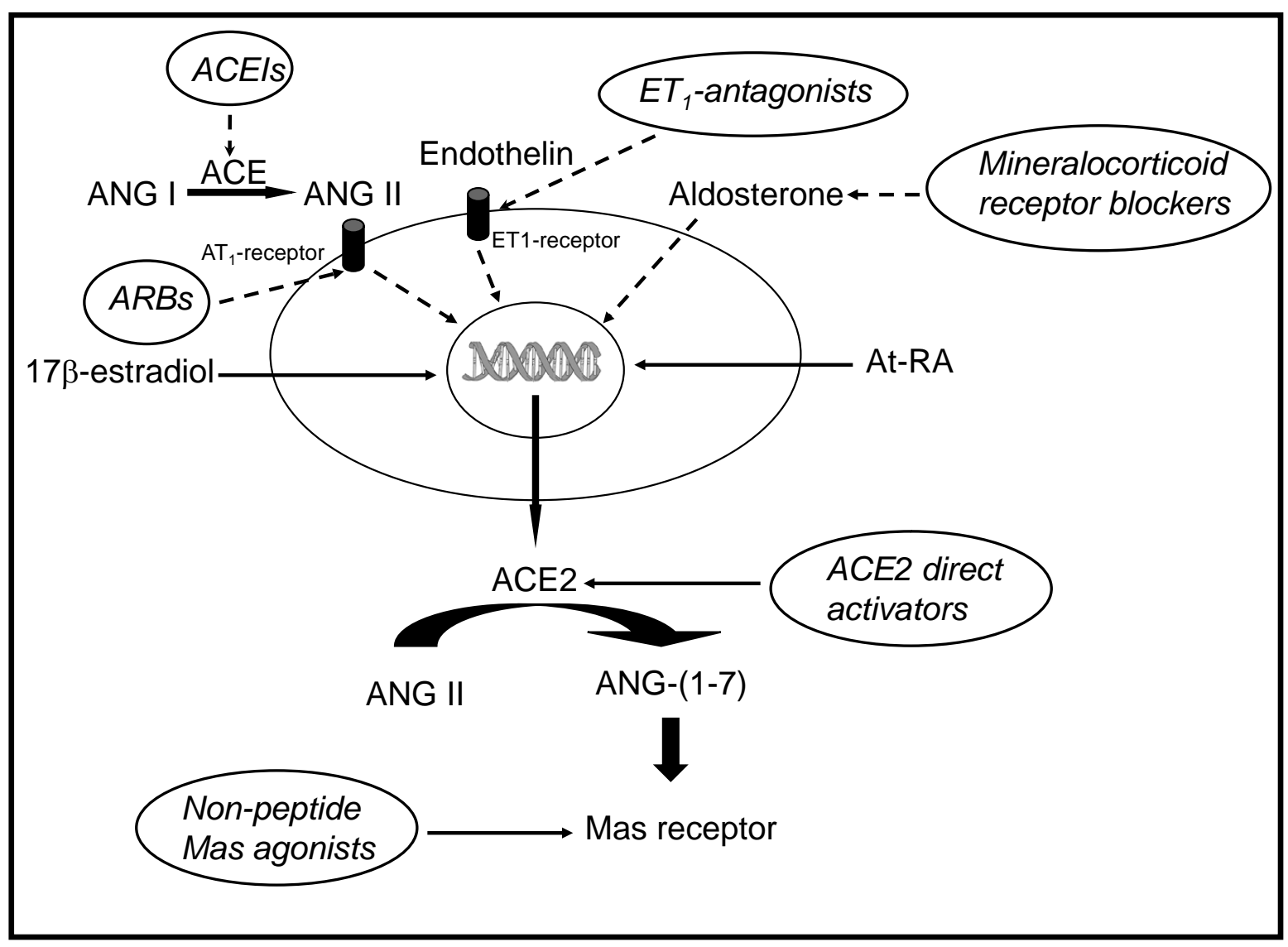

Fig. (3). Pharmacological modulation of the ACE2-ANG-(1-7)-Mas receptor axis. Continuous and dotted line represent a stimulatory and inhibitory action, respectively. Abbreviations: ACE: angiotensin-converting enzyme; ACEIs: angiotensin-converting enzyme inhibitors; ARBs: AT1-receptor blockers; At-RA: All-trans retinoic acid.

Considering the pivotal role of ACE2 in Ang-(1-7) biosynthesis, an interesting therapeutic approach to enhance Mas receptor stimulation is the upregulation of this enzyme. Expression and activity of ACE2 are regulated by several endogenous factors. Cytokines, like interferon $\gamma$ and interleukin 4 [81], Ang II [82], aldosterone [83, 84] and endothelin-1 [82] reduce ACE2 expression by a genomic effect. Ang II-induced downregulation of ACE2 is mediated by $\mathrm{AT}_{1}$ receptor stimulation. Gallagher et al. [82] have demonstrated that both Ang II and endothelin-1 downregulates ACE2 expression by a mechanism involving activation of the MAP kinases (ERK1 and/or ERK2).

Conversely, all-trans retinoic acid and $17 \beta$-estradiol have been found to up-regulate ACE2 protein and gene expression $[85,86]$. In addition, Ang-(1-7) and atrial natriuretic factor have been shown to prevent Ang II-induced downregulation of ACE2 [82].

Considering regulation of ACE2 activity, several therapeutic groups, including $\mathrm{ACE}$ inhibitors, $\mathrm{AT}_{1}$ receptor blockers, vasopeptidase inhibitors and mineralocorticoid receptor blockers, are able to increase endogenous Ang-(1-7) levels. ACE inhibitors increase endogenous levels of Ang(1-7) by 25 -fold through different mechanism [15], including increase of Ang-(1-7) synthesis by upregulation of ACE2 and greater disposition of precursors, and decrease of Ang(1-7) degradation [87]. Several works demonstrate that enhancement of endogenous Ang-(1-7) by ACE inhibitors is involved, at least in part, in several beneficial effects of this therapeutic group, including blood pressure lowering effect [25, 88-90], antithrombotic effect [91], and baroreflex improvement [92], among others. Conversely, van der Wouden et al. [93] have found that Ang-(1-7) plays no major role in the anti-proteinuric and blood pressure lowering effects of ACE inhibitors in an experimental model of nephrosis.

Similarly to $\mathrm{ACE}$ inhibitors, $\mathrm{AT}_{1}$ receptor antagonists also enhance Ang-(1-7) endogenous levels by as much as 25fold [9]. For this therapeutic group, Ang-(1-7) increment could be explained by the fact that Ang II affinity for $\mathrm{AT}_{1}$ receptors is 1000 times higher than its affinity to ACE2. Therefore, after blockade of $\mathrm{AT}_{1}$ receptors, Ang II would accumulate and be converted to Ang-(1-7) by ACE2. Another explanation is the fact that $\mathrm{AT}_{1}$ receptor antagonists induce overexpression and increased activity of ACE2 [15]. As described for ACE inhibitors, Ang-(1-7) also participates partially in the blood pressure lowering effect of $\mathrm{AT}_{1}$ receptor antagonists [89].

It is important to mention that enhancement of Ang-(1-7) levels also seems to contribute to the beneficial effects of aldosterone antagonists, such as spironolactone, in patients with heart failure. For instance, Keidar et al. [83] showed that chronic treatment of heart failure with spironolactone dramatically enhances ACE2 activity and its mRNA expression by $300 \%$ and $654 \%$, respectively. 
In addition, Choudhary et al. [94] have described that alltrans retinoic acid prevents development of cardiac remodeling in aortic banded rats by upregulation of expression of ACE2 and through inhibition of the expression of cardiac and renal renin, angiotensinogen, $\mathrm{ACE}$, and $\mathrm{AT}_{1}$ receptor.

More recently, direct inhibitors and activators of ACE2 have been developed. Although the inhibitor of ACE2, MLN-4760, has no therapeutic role, it has been used to define the role of the enzyme in diabetic nephropathy, considering that 16-week administration of the inhibitor worsened albuminuria in $\mathrm{db} / \mathrm{db}$ mice [95]. Hernandez Prada et al. [96], by in silico approach, selected a xanthenone (1-[[2(dimethylamino) ethyl]amino]-4-(hydroxymethyl)-7-[[(4methylphenyl) sulfonyl] oxy] 9H-xanthen-9-one) that is able to enhance ACE2 activity in a dose dependent manner. Administration of this compound in spontaneously hypertensive rats reduces blood pressure and reverses cardiac and renal fibrosis [96]. In addition, chronic administration of the xanthenone prevents pulmonary hypertension and right ventricular hypertrophy induced by monocrotaline injection [97].

Therapeutic use of Ang-(1-7) is theoretically precluded considering its short plasma half-life in rodents (about 10 min) by a rapid proteolysis due to ACE activity and its poor bioavailability and absorption by oral or topical routes, considering its peptidergic nature and its high water-solubility [7]. However, the plasma half-life is approximately $30 \mathrm{~min}-$ utes in humans [8]. Promising strategies have been proposed to increase the therapeutic potential of Ang-(1-7), including the use of liposomes as sustained and controlled release systems and cyclodextrins to improve peptide bioavailability by oral route [98]. Santos et al. [98] have demonstrated that inclusion of Ang-(1-7) in liposomes prolongs its biological activity by preventing its degradation and by the slow release of Ang-(1-7) from the liposome. However, it is important to mention that this strategy to improve Ang-(1-7) half-life has only been assessed after intracerebroventricular administration. Therefore, further studies are needed to establish the ability of liposome for sustained liberation of the peptide after systemic administration.

The design of non-peptidic receptor Mas agonists is probably the most attractive therapeutic strategy in order to enhance the beneficial physiological actions of the heptapeptide. In 2001, Aventis Pharma designed the first nonpeptide and orally active analog of Ang-(1-7), AVE 0991 (5-Formyl4-methoxy-2-phenyl-1-[[4-[2-(ethylaminocarbonylsulfonamido)5-isobutyl-3-thienyl]-phenyl]-methyl]-imidazole). AVE 0991 has a 10-fold higher affinity for Mas receptor than Ang-(1-7) [73]. Although the pharmacokinetic properties of this new chemical entity have not been studied, it is well known that AVE 0991 mimics Ang-(1-7) effects in several organs [99]. AVE 0991 evokes similar effects with regard to Ang-(1-7) in cultured bovine aortic endothelial cells [100], kidneys [101], and vessels [102, 103]. In addition, Benter et al. [64] showed that chronic administration of Ang-(1-7) or its synthetic analog, AVE 0991, significantly improved the ischemiareperfusion recovery in isolated perfused spontaneously hypertensive rat hearts treated with L-NAME. More recently, Ferreira et al. [104] have demonstrated the ability of AVE 0991 to attenuate post ischemic heart failure in a model of myocardial infarction induced by left coronary artery ligation. In addition, AVE 0991 also exerts a cardioprotective role on cardiac remodeling induced by cardiac $\beta$ adrenoceptor overstimulation [105]. Cardiac beneficial effects of AVE 0991 were also demonstrated in a preclinical model of type I diabetes mellitus. Chronic administration of the agonist prevented diabetic rats from severe systolic dysfunction without affecting glycemia [106]. Pharmacological actions of AVE 0991 are resumed in Table $\mathbf{1 .}$

Table 1. Pharmacological Effects of the Non-Peptide Mas Receptor Agonist AVE 0991

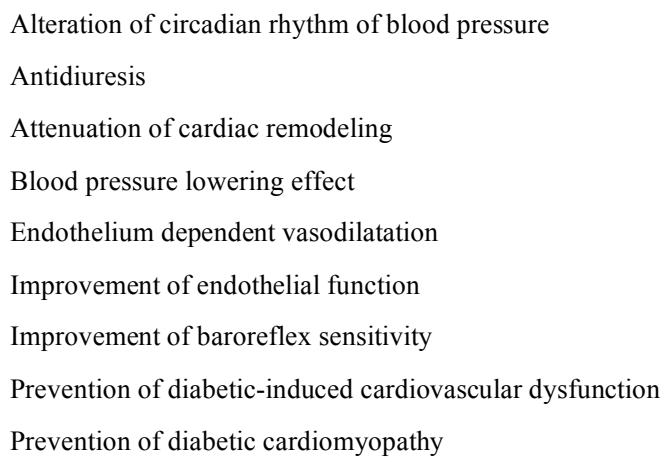

\section{LIMITATIONS}

Although a large amount of evidence, mainly from preclinical studies, supports a possible therapeutic role of drugs aimed at increasing activity of ACE2-Ang-(1-7)-Mas axis in the treatment of hypertension, diabetes, heart failure, among other cardiovascular diseases, there are several factors that could limit this new therapeutic strategy.

In first place, as mentioned above, most physiological actions of Ang-(1-7) are biphasic, and, consequently, higher doses of the heptapeptide would produce activation of $\mathrm{AT}_{1}$ receptor, probably reducing the beneficial effects of Mas receptor stimulation. Therefore, there is a need to clearly define the most adequate dosing of receptor Mas agonists in different clinical situations. Moreover, to the best our knowledge, selectivity of the non-peptide AVE 0991 for Mas receptor is actually unknown.

In second place, further research is needed to completely characterize Ang-(1-7) pharmacodynamics. Although identification of Mas receptor as cellular target of the heptapeptide greatly improves knowledge of physiological actions of Ang-(1-7), it is important to mention that some effects of Ang-(1-7) seem to be mediated by multiple receptors pathways and also blocked by administration of antagonists of Ang II and bradykinin receptors [3]. Therefore, concerns arise regarding the advantage of Mas receptor agonists in patients under treatment with $\mathrm{AT}_{1}$ receptor blockers.

Strategies aimed at increasing ACE2 activity to enhance Ang-(1-7) biosynthesis suffer from potential therapeutic limitations. Although Ang II is considered to be the main substrate for ACE2, this enzyme is also involved in the degradation of several other peptides, including apelin-13, neurotensin, kinestensin, dynorphin and bradykinin fragments [107]. Increased metabolism of dynorphin could be related to adverse effect such as hyperalgesia, considering the role of this peptide in central and peripheral regulation of pain [108]. In addition, neurotensin exerts brain actions as a pri- 
mary neurotransmitter or neuromodulator of classical neurotransmitters [109], and therefore administration of ACE2 activators could induce neurological adverse effects. Moreover, ACE2 also serves as the cellular entry point for the severe acute respiratory syndrome (SARS) virus [110], and therefore there are strong concerns regarding the safety of ACE2 up regulation.

In addition, we doubt that enhancers of Ang-(1-7)-Mas axis could potentiate beneficial effects of well established cardiovascular therapies. In this way, ACE inhibitors, $\mathrm{AT}_{1}$ receptor antagonists and aldosterone antagonists have been used along several years in the treatment of different cardiovascular diseases, including hypertension and chronic heart failure $[111,112]$. Moreover, these therapeutic groups have demonstrated to reduce mortality associated to chronic heart failure in several controlled clinical trials and are recommended as first-line therapy in different stages of heart failure [112]. As previously mentioned, it has been shown that $\mathrm{ACE}$ inhibitors, $\mathrm{AT}_{1}$ receptor antagonists and aldosterone antagonists are able to increase ACE2 activity and/or Ang(1-7) levels and several lines of evidence have demonstrated that enhancement of the heptapeptide endogenous levels is partially involved in the beneficial effects of ACE inhibitors and $\mathrm{AT}_{1}$ receptor antagonists [25, 88-92].

In addition, beneficial effects of ACE inhibitors are also mediated through an increment of bradykinin, $\mathrm{PGI}_{2}$ and an enhancement of NO disposition [113]. As previously mentioned, most physiological actions of Ang-(1-7) partially involve these endogenous compounds.

Considering these aspects, it is improbable that exogenous administration of Ang-(1-7) agonists or increase of endogenous levels of the heptapeptide by means of direct ACE2 activation could increase cardiovascular beneficial effects in patients treated with traditional drugs acting on the RAS, considering that these strategies share similar mechanism of actions.

\section{CONCLUSIONS}

Nowadays, several investigational lines have clearly demonstrated a protective role of Ang-(1-7) on the cardiovascular system. Increasing endogenous Ang-(1-7) levels limits the deleterious effect of Ang II through activation of the Mas receptor and by up regulating the action of several cellular mediators, including NO, prostaglandins and bradykinin, among others. In addition, Mas receptor activation seems to regulate the activity of Ang II receptors, such as $\mathrm{AT}_{1}$ and $\mathrm{AT}_{2}$ receptors, considering that several beneficial effects of Ang-(1-7) are prevented after blocked of these receptors. Activation of Mas receptor, either by enhancement of endogenous Ang-(1-7) concentrations or by application of a Mas receptor agonist, could have a therapeutic role in the treatment of several cardiovascular diseases.

Although several lines of evidence have clearly demonstrated that enhancement of Ang-(1-7) endogenous levels contributes to the beneficial effect of established RAS blockers, including ACEIs, $\mathrm{AT}_{1}$ receptor antagonists and aldosterone receptor blockers, the therapeutic role of specific agents aimed to increase Mas receptor activation, such as ACE2 modulators or non-peptide Mas receptor agonists, has not been established yet.

\section{REFERENCES}

[1] Paul, M.; Mehr, A.P.; Kreutz, R. Physiology of local reninangiotensin systems. Physiol. Rev., 2006, 86, 747-803.

[2] Santos, R.A.; Simoes e Silva, A.C.; Maric, C.; Silva, D.M.; Machado, R.P.; de Buhr, I.; Heringer-Walther, S.; Pinheiro, S.V.; Lopes, M.T.; Bader, M.; Mendes, E.P.; Lemos, V.S.; CampagnoleSantos, M.J.; Schultheiss, H.P.; Speth, R.; Walther, T. Angiotensin(1-7) is an endogenous ligand for the G protein-coupled receptor Mas. Proc. Natl. Acad. Sci. USA, 2003, 100, 8258-8263.

[3] Iusuf, D.; Henning, R.H.; van Gilst, W.H.; Roks, A.J. Angiotensin(1-7): pharmacological properties and pharmacotherapeutic perspectives. Eur. J. Pharmacol., 2008, 585, 303-312.

[4] Kostenis, E.; Milligan, G.; Christopoulos, A.; Sanchez-Ferrer, C.F.; Heringer-Walther, S.; Sexton, P.M.; Gembardt, F.; Kellett, E.; Martini, L.; Vanderheyden, P.; Schultheiss, H.P.; Walther, T. G-protein-coupled receptor Mas is a physiological antagonist of the angiotensin II type 1 receptor. Circulation, 2005, 111, 1806-1813.

[5] Höcht, C.; Mayer, M.A.; Taira, C.A. Advances in the Physiology and Pharmacology of Angiotensin. In: Angiotensin Research Progress. Miura, H.; Sasaki, Y.; Eds. Nova Sience Publishers, 2008, Vol. 1; pp 147-171,.

[6] Vickers, C.; Hales, P.; Kaushik, V.; Dick, L.; Gavin, J.; Tang, J.; Godbout, K.; Parsons, T.; Baronas, E.; Hsieh, F.; Acton, S.; Patane, M.; Nichols, A.; Tummino, P. Hydrolysis of biological peptides by human angiotensin-converting enzyme-related carboxypeptidase. $J$. Biol. Chem., 2002, 277, 14838-14843.

[7] Yamada, K.; Iyer, S.N.; Chappell, M.C.; Ganten, D.; Ferrario, C.M. Converting enzyme determines plasma clearance of angiotensin-(1-7). Hypertension, 1998, 32, 496-502.

[8] Rodgers, K.E.; Ellefson, D.D.; Espinoza, T.; Hsu, Y.H.; diZerega, G.S.; Mehrian-Shai, R. Expression of intracellular filament, collagen, and collagenase genes in diabetic and normal skin after injury. Wound Repair Regen., 2006, 14, 298-305.

[9] Allred, A.J.; Diz, D.I.; Ferrario, C.M.; Chappell, M.C. Pathways for angiotensin-(1-7) metabolism in pulmonary and renal tissues. Am. J. Physiol. Renal Physiol., 2000, 279, 841-850.

[10] Santos, R.A.; Ferreira, A.J. Angiotensin-(1-7) and the reninangiotensin system. Curr. Opin. Nephrol. Hypertens., 2007, 16, $122-128$.

[11] Santos, R.A.; Campagnole-Santos, M.J.; Baracho, N.C.; Fontes, M.A.; Silva, L.C.; Neves, L.A.; Oliveira, D.R.; Caligiorne, S.M.; Rodrigues, A.R.; Gropen Júnior, C.; Carvalho, W.S.; Simoes E.; Silva, A.C.; Khosla, M.C. Characterization of a new antagonist selective for angiotensin-(1-7): evidence that the actions of angiotensin-(1-7) are mediated by specific angiotensin receptors. Brain Res. Bull., 1994, 35, 293-298.

[12] Silva, D.M.; Vianna, H.R.; Cortes, S.F.; Campagnole-Santos, M.J.; Santos, R.A.; Lemos, V.S. Evidence for a new angiotensin-(1-7) receptor subtype in the aorta of Sprague-Dawley rats. Peptides, 2007, 28, 702-707.

[13] Sampaio, W.O.; Souza dos Santos, R.A.; Faria-Silva, R.; da Mata Machado, L.T.; Schiffrin, E.L.; Touyz, R.M. Angiotensin-(1-7) through receptor mas mediates endothelial nitric oxide synthase activation via Akt-dependent pathways. Hypertension, 2007, 49, 185192.

[14] Tallant, E.A.; Ferrario, C.M.; Gallagher, P.E. Angiotensin-(1-7) inhibits growth of cardiac myocytes through activation of the mas receptor. Am. J. Physiol. Heart Circ. Physiol., 2005, 289, 15601566.

[15] Ferrario, C.M.; Trask, A.J.; Jessup, J.Á. Advances in biochemical and functional roles of angiotensin-converting enzyme 2 and angiotensin-(1-7) in regulation of cardiovascular function. Am. J. Physiol. Heart Circ. Physiol., 2005, 289, 2281-2290.

[16] Su, Z.; Zimpelmann, J.; Burns, K.D. Angiotensin-(1-7) inhibits angiotensin II-stimulated phosphorylation of MAP kinases in proximal tubular cells. Kidney Inter., 2005, 69, 2212-2218.

[17] Giani, J.F.; Gironacci, M.M.; Muñoz, M.C.; Peña, C.; Turyn, D.; Dominici, F.P. Angiotensin-(1 7) stimulates the phosphorylation of JAK2, IRS-1 and Akt in rat heart in vivo: role of the AT1 and Mas receptors. Am. J. Physiol. Heart Circ. Physiol., 2007, 293, H1154H1163.

[18] Santos, R.A.; Ferreira, A.J.; Pinheiro, S.V.; Sampaio, W.O.; Touyz, R.; Campagnole-Santos, M.J. Angiotensin-(1-7) and its receptor as a potential targets for new cardiovascular drugs. Expert Opin. Investig. Drugs, 2005, 14, 1019-1031. 
[19] Oudit, G.Y.; Kassiri, Z.; Patel, M.P.; Chappell, M.; Butany, J.; Backx, P.H.; Tsushima, R.G.; Scholey, J.W.; Khokha, R.; Penninger, J.M. Angiotensin II oxidative stress and inflammation mediate the age dependent cardiomyopathy in ACE2 null mice. Cardiovasc. Res., 2007, 75, 29-39.

[20] Jaiswal, N.; Diz, D.I.; Chappell, M.C.; Khosla, M.C.; Ferrario, C.M. Stimulation of endothelial cell prostaglandin production by angiotensin peptides. Characterization of receptors. Hypertension, 1992, 19, II49-II55.

[21] Jaiswal, N.; Tallant, E.A.; Jaiswal, R.K.; Diz, D.I.; Ferrario, C.M. Differential regulation of prostaglandin synthesis by angiotensin peptides in porcine aortic smooth muscle cells: subtypes of angiotensin receptors involved. J. Pharmacol. Exp. Ther., 1993, 265, 664-673.

[22] Muthalif, M.M.; Benter, I.F.; Uddin, M.R.; Harper, J.L.; Malik, K.U. Signal transduction mechanisms involved in angiotensin-(17)-stimulated arachidonic acid release and prostanoid synthesis in rabbit aortic smooth muscle cells. J. Pharmacol. Exp. Ther. 1998, 284, 388-398.

[23] Rowe, B.P.; Saylor, D.L.; Speth, R.C.; Absher, D.R. Angiotensin(1-7) binding at angiotensin II receptors in the rat brain. Regul. Pept., 1995, 56, 139-146.

[24] Tallant, E.A.; Lu, X.; Weiss, R.B.; Chappell, M.C.; Ferrario, C.M. Bovine aortic endothelial cells contain an angiotensin-(1-7) receptor. Hypertension, 1997, 29, 388-393.

[25] Höcht, C.; Gironacci, M.M.; Mayer, M.A.; Schuman, M.; Bertera, F.M.; Taira, C.A. Involvement of angiotensin-(1-7) in the hypothalamic hypotensive effect of captopril in sinoaortic denervated rats. Regul. Pept., 2008, 146, 58-66.

[26] Lyngsø, C.; Erikstrup, N.; Hansen, J.L. Functional interactions between 7TM receptors in the Renin-Angiotensin SystemDimerization or crosstalk? Mol. Cell Endocrinol., 2008, 284, 18311839.

[27] Campbell, D.J. The renin-angiotensin and the kallikrein-kinin systems. Int. J. Biochem. Cell Biol., 2003, 35, 784-791.

[28] Fraga-Silva, R.A.; Pinheiro, S.V.; Gonçalves, A.C.; Alenina, N.; Bader, M.; Santos, R.A. The antithrombotic effect of angiotensin(1-7) involves mas-mediated NO release from platelets. Mol. Med., 2008, 14, 28-35.

[29] Kucharewicz, I.; Chabielska, E.; Pawlak, D.; Matys, T.; Rólkowski, R.; Buczko, W. The antithrombotic effect of angiotensin-(1-7) closely resembles that of losartan. J. Renin Angiotensin Aldosterone Syst., 2000, 1, 268-272.

[30] Sasaki, S.; Higashi, Y.; Nakagawa, K.; Matsuura, H.; Kajiyama, G.; Oshima, T. Effects of angiotensin-(1-7) on forearm circulation in normotensive subjects and patients with essential hypertension. Hypertension, 2001, 38, 90-94.

[31] Haulica, I.; Bild, W.; Mihaila, C.N.; Ionita, T.; Boisteanu, C.P.; Neagu, B. Biphasic effects of angiotensin (1-7) and its interactions with angiotensin II in rat aorta. J. Renin Angiotensin Aldosterone Syst., 2003, 4, 124-128.

[32] Peiró, C.; Vallejo, S.; Gembardt, F.; Azcutia, V.; Heringer-Walther, S.; Rodríguez-Mañas, L.; Schultheiss, H.P.; Sánchez-Ferrer, C.F.; Walther, T. Endothelial dysfunction through genetic deletion or inhibition of the G protein-coupled receptor Mas: a new target to improve endothelial function. J. Hypertens., 2007, 25, 2421-2425.

[33] Baracho, N.C.V.; Simões e Silva, A.C.; Khosla, M.C.; Santos, R.A. Effect of selective angiotensin antagonists on the antidiuresis produced by angiotensin-(1-7) in water-loaded rats. Braz. J. Med. Biol. Res., 1998, 31, 1221-1227.

[34] Santos, R.A.; Simões e Silva, A.C.; Magaldi, A.J.; Khosla, M.C.; Cesar, K.R.; Passaglio, K.T.; Baracho, N.C. Evidence for a physiological role of angiotensin-(1-7) in the control of hydroelectrolyte balance. Hypertension, 1996, 27, 875-884.

[35] Magaldi, A.J.; Cesar, K.R.; de Araújo, M.; Simões e Silva, A.C.; Santos, R.A. Angiotensin-(1-7) stimulates water transport in rat inner medullary collecting duct: evidence for involvement of vasopressin V2 receptors. Pflugers Arch., 2003, 447, 223-230.

[36] Santos, R.A.S.; Campagnole-Santos, M.J.; Andrade, S.P. Angiotensin-(1-7): an update. Regul. Pept., 2000, 91, 45-62.

[37] Gironacci, M.M. Contribution of angiotensin-(1-7) to the pathophysiology of hypertension. Braz. J. Hypertens., 2005, 12, 147-52.

[38] Campagnole-Santos, M.J.; Heringer, S.B.; Batista, E.N.; Khosla, M.C.; Santos, R.A. Differential baroreceptor reflex modulation by centrally infused angiotensin peptides. Am. J. Physiol., 1992, 263, R89-R94.
[39] Dobruch, J.; Paczwa, P.; Łoń, S.; Khosla, M.C.; SzczepańskaSadowska, E. Hypotensive function of the brain angiotensin-(1-7) in Sprague Dawley and renin transgenic rats. J. Physiol. Pharmacol., 2003, 54, 371-381.

[40] Moriguchi, A.; Tallant, E.A.; Matsumura, K.; Reilly, T.M.; Walton, H.; Ganten, D.; Ferrario, C.M. Opposing actions of angiotensin-(1-7) and angiotensin II in the brain of transgenic hypertensive rats. $\mathrm{Hy}$ pertension, 1995, 25, 1260-1265.

[41] Höcht, C.; Opezzo, J.A.; Gironacci, M.M.; Peña, C.; Taira, C.A Hypothalamic cardiovascular effects of Ang-(1-7) in spontaneously hypertensive rats. Regul. Pept., 2006, 135, 39-44.

[42] Ferrario, C.M.; Chappell, M.C.; Dean, R.H.; Iyer, S.N. Novel angiotensin peptides regulate blood pressure, endothelial function, and natriuresis. J. Am. Soc. Nephrol., 1998, 9, 1716-1722.

[43] Gorelik, G.; Carbini, L.A.; Scicli, A.G. Angiotensin 1-7 induces bradykinin-mediated relaxation in porcine coronary artery. $J$. Pharmacol. Exp. Ther., 1998, 286, 403-410.

[44] Brosnihan, K.B.; Li, P.; Ferrario, C.M. Angiotensin-(1-7) dilates canine coronary arteries through kinins and nitric oxide. Hypertension, 1996, 27, 523-528.

[45] Castro, C.H.; Santos, R.A.; Ferreira, A.J.; Bader, M.; Alenina, N.; Almeida, A.P. Evidence for a functional interaction of the angiotensin-(1-7) receptor Mas with AT1 and AT2 receptors in the mouse heart. Hypertension, 2005, 46, 937-942.

[46] Neves, L.A.; Almeida, A.P.; Khosla, M.C.; Campagnole-Santos, M.J.; Santos, R.A. Effect of angiotensin-(1-7) on reperfusion arrhythmias in isolated rat hearts. Braz. J. Med. Biol. Res., 1997, 30, 801-809.

[47] Ehrlich, J.R.; Hohnloser, S.H.; Nattel, S. Role of angiotensin system and effects of its inhibition in atrial fibrillation: clinical and experimental evidence. Eur. Heart J., 2006, 27, 512-518.

[48] Ferreira, A.J.; Santos, R.A.; Almeida, A.P. Angiotensin (1-7): cardioprotective effect in myocardial ischemia/reperfusion. Hypertension, 2001, 38, 665-668.

[49] De Mello, W.C.; Ferrario, C.M.; Jessup, J.A. Beneficial vs harmful effects of Angiotensin (1-7) on impulse propagation and cardiac arrhythmias in the failing heart. J. Renin Angiotensin Aldosterone Syst., 2007, 8, 74-80.

[50] Huentelman, M.J.; Grobe, J.L.; Vazquez, J.; Stewart, J.M.; Mecca A.P.; Katovich, M.J.; Ferrario, C.M.; Raizada, M.K. Protection from angiotensin II-induced cardiac hypertrophy and fibrosis by systemic lentiviral delivery of ACE2. Exp. Physiol., 2005, 90, 783790.

[51] Díez-Freire, C.; Vázquez, J.; Correa de Adjounian, M.F.; Ferrari, M.F.; Yuan, L.; Silver, X.; Torres, R.; Raizada, M.K. ACE2 gene transfer attenuates hypertension-linked pathophysiological changes in the SHR. Physiol. Genom., 2006, 27, 12-19.

[52] Grobe, J.L.; Mecca, A.P.; Mao, H.; Katovich, M.J. Chronic angiotensin-(1-7) prevents cardiac fibrosis in the DOCA-salt model of hypertension. Am. J. Physiol. Heart Circ. Physiol., 2006, 290, H2417-H2423.

[53] Santos, R.A.; Ferreira, A.J.; Nadu, A.P.; Braga, A.N.; de Almeida, A.P.; Campagnole-Santos, M.J.; Baltatu, O.; Iliescu, R.; Reudelhuber, T.L.; Bader, M. Expression of an angiotensin-(1-7)producing fusion protein produces cardioprotection effects in rats. Physiol. Genom., 2004, 17, 292-299.

[54] Grobe, J.L.; Mecca, A.P.; Lingis, M.; Shenoy, V.; Bolton, T.A.; Machado, J.M.; Speth, R.C.; Raizada, M.K.; Katovich, M.J. Prevention of angiotensin II-induced cardiac remodeling by angiotensin-(1-7). Am. J. Physiol. Heart Circ. Physiol., 2007, 292, H736H742.

[55] Iwata, M.; Cowling, R.T.; Gurantz, D.; Moore, C.; Zhang, S.; Yuan, J.X.; Greenberg, B.H. Angiotensin-(1-7) binds to specific receptors on cardiac fibroblasts to initiate antifibrotic and antitrophic effects. Am. J. Physiol. Heart Circ. Physiol., 2005, 289, H2356$\mathrm{H} 2363$.

[56] Mercure, C.; Yogi, A.; Callera, G.E.; Aranha, A.B.; Bader, M.; Ferreira, A.J.; Santos, R.A.; Walther, T.; Touyz, R.M.; Reudelhuber, T.L. Angiotensin-(1-7) blunts hypertensive cardiac remodeling by a direct effect on the heart. Circ. Res., 2008, 103, 13191326.

[57] Tallant, E.A.; Diz, D.I.; Ferrario, C.M. Antiproliferative actions of angiotensin-(1-7) in vascular smooth muscle. Hypertension, 1999, $34,950-957$. 
[58] Tallant, E.A.; Clark, M.A. Molecular mechanisms of inhibition of vascular growth by angiotensin-(1-7). Hypertension, 2003, 42, 574579.

[59] Rentzsch, B.; Todiras, M.; Iliescu, R.; Popova, E.; Campos, L.A.; Oliveira, M.L.; Baltatu, O.C.; Santos, R.A.; Bader, M. Transgenic angiotensin-converting enzyme 2 overexpression in vessels of SHRSP rats reduces blood pressure and improve endothelial function. Hypertension, 2008, 52, 967-973.

[60] Freeman, E.J.; Chisolm, G.M.; Ferrario, C.M.; Tallant, E.A. Angiotensin-(1-7) inhibits vascular smooth muscle cell growth. Hypertension, 1996, 28, 104-108.

[61] Strawn, W.B.; Ferrario, C.M.; Tallant, E.A. Angiotensin-(1-7) reduces smooth muscle growth after vascular injury. Hypertension, 1999, 30, 535-541.

[62] Rodgers, K.E.; Oliver, J.; diZerega, G.S. Phase I/II dose escalation study of angiotensin 1-7 [A(1-7)] administered before and after chemotherapy in patients with newly diagnosed breast cancer. Cancer Chemother. Pharmacol., 2006, 57, 559-568.

[63] Widdop, R.E.; Sampey, D.B.; Jarrott, B. Cardiovascular effects of angiotensin-(1-7) in conscious spontaneously hypertensive rats. Hypertension, 1999, 34, 964-968.

[64] Benter, I.F.; Yousif, M.H.; Anim, J.T.; Cojocel, C.; Diz, D.I. Angiotensin-(1-7) prevents development of severe hypertension and end-organ damage in spontaneously hypertensive rats treated with L-NAME. Am. J. Physiol. Heart Circ. Physiol., 2006, 290, H684H691.

[65] Iyer, S.N.; Averill, D.B.; Chappell, M.C.; Yamada, K.; Allred, A.J.; Ferrario, C.M. Contribution of angiotensin-(1-7) to blood pressure regulation in salt-depleted hypertensive rats. Hypertension, 2000, $36,417-422$

[66] Ferrario, C.M.; Martell, N.; Yunis, C.; Flack, J.M.; Chappell, M.C.; Brosnihan, K.B.; Dean, R.H.; Fernandez, A.; Novikov, S.V.; Pinillas, C.; Luque, M. Characterization of angiotensin-(1-7) in the urine of normal and essential hypertensive subjects. Am. J. Hypertens., 1998, 11, 137-146.

[67] Loot, A.E.; Roks, A.J.; Henning, R.H.; Tio, R.A.; Suurmeijer, A.J.; Boomsma, F.; van Gilst, W.H. Angiotensin-(1-7) attenuates the development of heart failure after myocardial infarction in rats. Circulation, 2002, 105, 1548-1550.

[68] Katovich, M.J.; Grobe, J.L.; Raizada, M.K. Angiotensin-(1-7) as an antihypertensive, antifibrotic target. Curr. Hypertens. Rep., 2008, 10, 227-232.

[69] Burrell, L.M.; Risvanis, J.; Kubota, E.; Dean, R.G.; MacDonald, P.S.; Lu, S.; Tikellis, C.; Grant, S.L.; Lew, R.A.; Smith, A.I.; Cooper, M.E.; Johnston, C.I. Myocardial infarction increases ACE2 expression in rat and humans. Eur. Heart J., 2005, 26, 369-375.

[70] Zisman, L.S.; Keller, R.S.; Weaver, B.; Lin, Q.; Speth, R.; Bristow, M.R.; Canver, C.C. Increased angiotensin-(1-7)-forming activity in failing human heart ventricles: evidence for upregulation of the angiotensin-converting enzyme Homologue ACE2. Circulation, 2003, 108, 1707-1712.

[71] Benter, I.F.; Yousif, M.H.; Cojocel, C.; Al-Maghrebi, M.; Diz, D.I. Angiotensin-(1-7) prevents diabetes-induced cardiovascular dysfunction. Am. J. Physiol. Heart Circ. Physiol., 2007, 292, H666H672.

[72] Tikellis, C.; Johnston, C.I.; Forbes, J.M.; Burns, W.C.; Burrell, L.M.; Risvanis, J.; Cooper, M.E. Characterization of renal angiotensin-converting enzyme 2 in diabetic nephropathy. Hypertension, 2003, 41, 392-397.

[73] Wysocki, J.; Ye, M.; Soler, M.J.; Gurley, S.B.; Xiao, H.D.; Bernstein, K.E.; Coffman, T.M.; Chen, S.; Batlle, D. ACE and ACE2 activity in diabetic mice. Diabetes, 2006, 55, 2132-2139.

[74] Giani, J.F.; Mayer, M.A.; Muñoz, M.C.; Silberman, E.A.; Höcht, C.; Taira, C.A.; Gironacci, M.M.; Turyn, D.; Dominici, F.P. Chronic infusion of angiotensin-(1-7) improves insulin resistance and hypertension induced by a high-fructose diet in rats. Am. J. Physiol. Endocrinol. Metab., 2009, 296, E262-E271.

[75] Gallagher, P.E.; Tallant, E.A. Inhibition of human lung cancer cell growth by angiotensin-(1-7). Carcinogenesis, 2004, 25, 2045-2052.

[76] Ellefson, D.D.; diZerega, G.S.; Espinoza, T.; Roda, N.; Maldonado, S.; Rodgers, K.E. Synergistic effects on co-administration of Angiotensin 1-7 and Neupogen on hematopoietic recovery in mice. Cancer Chemother. Pharmacol., 2004, 53, 15-24.

[77] Rodgers, K.E.; Espinoza, T.; Felix, J.; Roda, N.; Maldonado, S.; diZerega, G. Acceleration of healing, reduction of fibrotic scar, and normalization of tissue architecture by an angiotensin analogue, NorLeu3-A(1-7). Plast. Reconstr. Surg., 2003, 111, 1195-1206.

[78] Kuba, K.; Imai, Y.; Rao, S.; Gao, H.; Guo, F.; Guan, B.; Huan, Y.; Yang, P.; Zhang, Y.; Deng, W.; Bao, L.; Zhang, B.; Liu, G.; Wang, Z.; Chappell, M.; Liu, Y.; Zheng, D.; Leibbrandt, A.; Wada, T.; Slutsky, A.S.; Liu, D.; Qin, C.; Jiang, C.; Penninger, J.M. A crucial role of angiotensin converting enzyme 2 (ACE2) in SARS coronavirus-induced lung injury. Nat. Med., 2005, 11, 875-879.

[79] Imai, Y.; Kuba, K.; Penninger, J.M. The discovery of angiotensin-converting enzyme 2 and its role in acute lung injury in mice. Exp. Physiol., 2009, 93, 543-548.

[80] Lovren, F.; Pan, Y.; Quan, A.; Teoh, H.; Wang, G.; Shukla, P.C.; Levitt, K.S.; Oudit, G.Y.; Al-Omran, M.; Stewart, D.J.; Slutsky, A.S.; Peterson, M.D.; Backx, P.H.; Penninger, J.M.; Verma, S. Angiotensin converting enzyme-2 confers endothelial protection and attenuates atherosclerosis. Am. J. Physiol. Heart Circ. Physiol., 2008, 295, H1377-H1384.

[81] de Lang, A.; Osterhaus, A.D.; Haagmans, B.L. Interferon-gamma and interleukin-4 downregulate expression of the SARS coronavirus receptor ACE2 in Vero E6 cells. Virology, 2006, 353, 474-481.

[82] Gallagher, P.E.; Ferrario, C.M.; Tallant, E.A. Regulation of ACE2 in Cardiac Myocytes and Fibroblasts. Am. J. Physiol. Heart Circ. Physiol., 2008, 295, H2373-2379.

[83] Keidar, S.; Gamliel-Lazarovich, A.; Kaplan, M.; Pavlotzky, E.; Hamoud, S.; Hayek, T.; Karry, R.; Abassi, Z. Mineralocorticoid receptor blocker increases angiotensin-converting enzyme 2 activity in congestive heart failure patients. Circ. Res., 2005, 97, 946-953.

[84] Yamamuro, M.; Yoshimura, M.; Nakayama, M.; Abe, K.; Sumida, H.; Sugiyama, S.; Saito, Y.; Nakao, K.; Yasue, H.; Ogawa, H. Aldosterone, but not angiotensin II, reduces angiotensin converting enzyme 2 gene expression levels in cultured neonatal rat cardiomyocytes. Circ. J., 2008, 72, 1346-1350.

[85] Zhong, J.C.; Huang, D.Y.; Yang, Y.M.; Li, Y.F.; Liu, G.F.; Song, X.H.; Du, K. Upregulation of angiotensin-converting enzyme 2 by all-trans retinoic acid in spontaneously hypertensive rats. Hypertension, 2004, 44, 907-912.

[86] Ji, H.; Menini, S.; Zheng, W.; Pesce, C.; Wu, X.; Sandberg, K. Role of angiotensin-converting enzyme 2 and angiotensin(1-7) in 17beta-oestradiol regulation of renal pathology in renal wrap hypertension. Exp. Physiol., 2008, 93, 648-657.

[87] Ferrario, C.M.; Jessup, J.; Gallagher, P.E.; Averill, D.B.; Brosnihan, K.B.; Ann Tallant, E.; Smith, R.D.; Chappell, M.C. Effects of renin-angiotensin system blockade on renal angiotensin (1-7) forming enzymes and receptors. Kidney Int., 2005, 68, 2189-2196.

[88] Maia, L.G.; Ramos, M.C.; Fernandes, L.; de Carvalho, M.H.; Campagnole-Santos, M.J.; Souza dos Santos, R.A. Angiotensin-(1-7) antagonist A-779 attenuates the potentiation of bradykinin by captopril in rats. J. Cardiovasc. Pharmacol., 2004, 3, 685-691.

[89] Iyer, S.N.; Ferrario, C.M.; Chappell, M.C. Angiotensin-(1-7) contributes to the antihypertensive effects of blockade of the reninangiotensin system. Hypertension, 1998, 31, 356-361.

[90] Fernandes, L.; Fortes, Z.B.; Casarini, D.E.; Nigro, D.; Tostes, R.C.; Santos, R.A.; de Carvalho, M.H. Role of PGI2 and effects of ACE inhibition on the bradykinin potentiation by angiotensin-(1-7) in resistance vessels of SHR. Regul. Pept., 2005, 127, 183-189.

[91] Kucharewicz, I.; Pawlak, R.; Matys, T.; Pawlak, D.; Buczko, W. Antithrombotic effect of captopril and losartan is mediated by angiotensin-(1-7). Hypertension, 2002, 40, 774-779.

[92] Heringer-Walther, S.; Batista, E.N.; Walther, T.; Khosla, M.C.; Santos, R.A.; Campagnole-Santos, M.J. Baroreflex improvement in SHR after ACEinhibition involves angiotensin-(1-7). Hypertension, 2001, 37, 1309-1314.

[93] van der Wouden, E.A.; Henning, R.H.; Deelman, L.E.; Roks, A.J.; Boomsma, F.; de Zeeuw, D. Does angiotensin (1-7) contribute to the anti-proteinuric effect of ACE-inhibitors. J. Renin Angiotensin Aldosterone Syst., 2005, 6, 96-101.

[94] Choudhary, R.; Palm-Leis, A.; Scott, R.C. 3rd; Guleria, R.S.; Rachut, E.; Baker, K.M.; Pan, J. All-trans retinoic acid prevents development of cardiac remodeling in aortic banded rats by inhibiting the renin-angiotensin system. Am. J. Physiol. Heart Circ. Physiol., 2008, 294, H633-H644.

[95] Ye, M.; Wysocki, J.; William, J.; Soler, M.J.; Cokic, I.; Batlle, D. Glomerular localization and expression of Angiotensin-converting enzyme 2 and Angiotensin-converting enzyme: implications for albuminuria in diabetes. J. Am. Soc. Nephrol., 2006, 17, 3067-3075. 
[96] Hernández Prada, J.A.; Ferreira, A.J.; Katovich, M.J.; Shenoy, V.; Qi, Y.; Santos, R.A.; Castellano, R.K.; Lampkins, A.J.; Gubala, V.; Ostrov, D.A.; Raizada, M.K. Structure-based identification of small-molecule angiotensin-converting enzyme 2 activators as novel antihypertensive agents. Hypertension, 2008, 51, 1312-1317.

[97] Ferreira, A.J.; Raizada, M.K. Are we poised to target ACE2 for the next generation of antihypertensives? J. Mol. Med., 2008, 86, 685690.

[98] Santos, R.A.S.; Frézard, F.; Ferreira, A.J. Angiotensin-(1-7): Blood, Heart, and Blood Vessels. Curr. Med. Chem. Cardiovasc. Hematol. Agents, 2005, 3, 383-391

[99] Santos, R.A.; Ferreira, A.J. Pharmacological effects of AVE 0991, a nonpeptide angiotensin-(1-7) receptor agonist. Cardiovasc. Drug Rev., 2006, 24, 239-246.

[100] Wiemer, G.; Dobrucki, L.W.; Louka, F.R.; Malinski, T.; Heitsch, H. AVE 0991, a nonpeptide mimic of the effects of angiotensin-(1-7) on the endothelium. Hypertension, 2002, 40, 847-852.

[101] Pinheiro, S.V.; Simões e Silva, A.C.; Sampaio, W.O.; de Paula, R.D.; Mendes, E.P.; Bontempo, E.D.; Pesquero, J.B.; Walther, T.; Alenina, N.; Bader, M.; Bleich, M.; Santos, R.A. Nonpeptide AVE 0991 is an angiotensin-(1-7) receptor Mas agonist in the mouse kidney. Hypertension, 2004, 44, 490-496.

[102] Faria-Silva, R.; Duarte, F.V.; Santos, R.A.S. Short-term angiotensin-(1-7) receptor Mas stimulation improves endothelial function in normotensive rats. Hypertension, 2005, 46, 948-952.

[103] Lemos, V.S.; Silva, D.M.; Walther, T.; Alenina, N.; Bader, M.; Santos, R.A. The endothelium-dependent vasodilator effect of the nonpeptide ANG-(1-7) mimic AVE 0991 is abolished in the aorta of Mas-knockout mice. J. Cardiovasc. Pharmacol., 2005, 46, 274-279.

[104] Ferreira, A.J.; Jacoby, B.A.; Araújo, C.A.; Macedo, F.A.; Silva, G.A.; Almeida, A.P.; Caliari, M.V.; Santos, R.A. The nonpeptide angiotensin-(1-7) receptor Mas agonist AVE-0991 attenuates heart failure induced by myocardial infarction. Am. J. Physiol. Heart Circ. Physiol., 2007, 292, H1113-H1119.

[105] Ferreira, A.J.; Oliveira, T.L.; Castro, M.C.; Almeida, A.P.; Castro,C.H.; Caliari, M.V.; Gava, E.; Kitten, G.T.; Santos, R.A. Isoproterenol-induced impairment of heart function and remodeling are attenuated by the nonpeptide angiotensin-(1-7) analogue AVE 0991. Life Sci., 2007, 81, 916-923.

[106] Ebermann, L.; Spillmann, F.; Sidiropoulos, M.; Escher, F.; Heringer-Walther, S.; Schultheiss, H.P.; Tschöpe, C.; Walther, T. The angiotensin-(1-7) receptor agonist AVE0991 is cardioprotective in diabetic rats. Eur. J. Pharmacol., 2008, 590, 276-280.

[107] Warner, F.J.; Smith, A.I.; Hooper, N.M.; Turner, A.J. Angiotensinconverting enzyme-2: a molecular and cellular perspective. Cell Mol. Life Sci., 2004, 61, 2704-2713.

[108] Holden, J.E.; Jeong, Y.; Forrest, J.M. The endogenous opioid system and clinical pain management. AACN Clin. Issues, 2005, 16, 291-301.
[109] Katsanos, G.S.; Anogianaki, A.; Castellani, M.L.; Ciampoli, C.; De Amicis, D.; Orso, C.; Pollice, R.; Vecchiet, J.; Tetè, S.; Salini, V.; Caraffa, A.; Patruno, A.; Shaik, Y.B.; Kempuraj, D.; Doyle, R.; Antinolfi, P.L.; Cerulli, G.; Conti, C.M.; Fulcheri, M.; Neri, G.; Sabatino, G. Biology of neurotensin: revisited study. Int. J. Immunopathol. Pharmacol., 2008, 21, 255-259.

[110] Turner, A.J.; Hiscox, J.A.; Hooper, N.M. ACE2: from vasopeptidase to SARS virus receptor. Trends Pharmacol. Sci., 2004, 25, 291-294.

[111] Mancia, G.; De Backer, G.; Dominiczak, A.; Cifkova, R.; Fagard, R.; Germano, G.; Grassi, G.; Heagerty, A.M.; Kjeldsen, S.E.; Laurent, S.; Narkiewicz, K.; Ruilope, L.; Rynkiewicz, A.; Schmieder, R.E.; Boudier, H.A.; Zanchetti, A.; Vahanian, A., Camm, J.; De Caterina, R.; Dean, V.; Dickstein, K.; Filippatos, G.; Funck-Brentano, C.; Hellemans, I.; Kristensen, S.D.; McGregor, K.; Sechtem, U.; Silber, S.; Tendera, M.; Widimsky, P.; Zamorano, J.L.; Erdine, S.; Kiowski, W.; Agabiti-Rosei, E.; Ambrosioni, E.; Lindholm, L.H.; Viigimaa, M.; Adamopoulos, S.; Agabiti-Rosei, E.; Ambrosioni, E.; Bertomeu, V.; Clement, D.; Erdine, S.; Farsang, C.; Gaita, D.; Lip, G.; Mallion, J.M.; Manolis, A.J.; Nilsson, P.M.; O'Brien, E.; Ponikowski, P.; Redon, J.; Ruschitzka, F.; Tamargo, J.; van Zwieten, P.; Waeber, B.; Williams, B.; Management of Arterial Hypertension of the European Society of Hypertension; European Society of Cardiology. 2007 Guidelines for the Management of Arterial Hypertension: The Task Force for the Management of Arterial Hypertension of the European Society of Hypertension (ESH) and of the European Society of Cardiology (ESC). J. Hypertens., 2007, 25, 1105-1187.

[112] Task Force for Diagnosis and Treatment of Acute and Chronic Heart Failure 2008 of European Society of Cardiology. Dickstein, K.; Cohen-Solal, A.; Filippatos, G.; McMurray, J.J.; Ponikowski, P.; Poole-Wilson, P.A.; Strömberg, A.; van Veldhuisen, D.J.; Atar, D.; Hoes, A.W.; Keren, A.; Mebazaa, A.; Nieminen, M.; Priori, S.G.; Swedberg, K.; ESC Committee for Practice Guidelines, Vahanian, A.; Camm, J.; De Caterina, R.; Dean, V.; Dickstein, K.; Filippatos, G.; Funck-Brentano, C.; Hellemans, I.; Kristensen, S.D.; McGregor, K.; Sechtem, U.; Silber, S.; Tendera, M.; Widimsky, P.; Zamorano, J.L. ESC Guidelines for the diagnosis and treatment of acute and chronic heart failure 2008: the Task Force for the Diagnosis and Treatment of Acute and Chronic Heart Failure 2008 of the European Society of Cardiology. Developed in collaboration with the Heart Failure Association of the ESC (HFA) and endorsed by the European Society of Intensive Care Medicine (ESICM). Eur. Heart J., 2008, 29, 2388-2442.

[113] Buczko, W.; Kramkowski, K.; Mogielnicki, A. Are the endothelial mechanisms of ACE-Is already established? Pharmacol. Rep., 2006, 58 (Suppl): 126-131. 